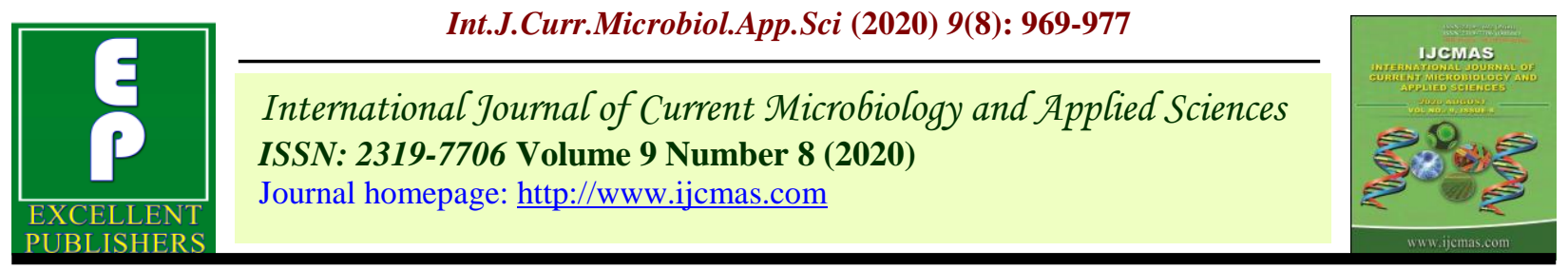

Original Research Article

https://doi.org/10.20546/ijcmas.2020.908.105

\title{
A Study on Adoption of Recommended Package of Practices by Rice Growers in Bandipora District of Jammu and Kashmir
}

\author{
Shijaatt Hussain Bhat*, Farhana, Anjali Tomar and S. S. Kubrevi
}

Division of Agri. Extension and Communication, SKUAST-Kashmir, Wadura, India

*Corresponding author

Keywords

Agriculture,

Adoption,

Rice, Growers

Article Info

Accepted:

10 July 2020

Available Online:

10 August 2020

\begin{abstract}
A B S T R A C T
The research study was conducted in Agricultural Zone Bandipora of Jammu and Kashmir state of India. In this research, the adoption of recommended package of practices of rice cultivation by growers were studied. Majority of the growers had adopted nonrecommended variety for sowing. Majority of the growers had adopted less than recommended spacing for transplanting seedlings and do not adopt any seed treatment. Majority of the growers had adopted recommended number of ploughings. Majority of the growers applied the FYM at more than the recommended rate, Urea at more than the recommended rate, DAP at less than the recommended rate and MOP at less than the recommended rate. Majority of growers applied the urea as $1 / 2$ at initial and other $1 / 2$ at transplanting stage. Majority $(67.00 \%)$ of the growers had medium level of adoption, followed by the low $(26.00 \%)$ and high $(7.00 \%)$ level of adoption respectively.
\end{abstract}

\section{Introduction}

Indian agriculture is considered to be backbone of Indian economy. About 72.20 per cent population lives in rural areas. The main occupation of rural people is agriculture. About 24.70 per cent of the national income originates from the agricultural sector. About 75.00 per cent of its population and 66.67 per cent of labour force, directly or indirectly is dependent on agriculture for livelihood. India accounts for only about 2.4 per cent of the world's geographical area and 4 per cent of its water resources but has to support about 17 per cent of the world's human population and 15 per cent of the livestock. Agriculture is an important sector of the Indian economy, accounting for 14 per cent of the nation's GDP, about 11per cent of its exports, about half of the population still relies on agriculture as principal source of income and it is a source of raw material for a large number of industries. The rate of growth in agriculture since independence has been 2.8 per cent per year, while, during the preindependence era it was 0.37 per cent only. Accelerating the growth of agriculture production therefore necessary not only to achieve an overall GDP target of 8 per cent during the 12th Plan and meet the rising demand for food, but also to increase incomes of those dependent on agriculture to ensure inclusiveness. (Anonymous, 2012-13). 
Rice is life, for most people of Asia. Rice has shaped the cultures, diets and economies of thousands of millions of people. It is central to the Asian way of life; deeply embedded in the cultural heritage, spirituality, traditions and norms (Ram, 2015). In Asia alone, more than 2,000 million people obtain 60 to 70 per cent of their calories from rice and its products. Recognizing the importance of this crop, the United Nations General Assembly declared 2004 as the "International Year of Rice" (IYR).

Paddy (Oryza sativa L.) is one of the important cereal crops of the world and forms the staple food for more than 50 per cent of population and is known as "king of cereals". Rice is an important food crop of India and stands first in area and second in total food production. Among the rice growing countries, India has the largest area under rice in the world (43.97 million ha) with a total production of 104.32 million tonnes during 2011-12 and it stood next only to China in the world with respect to production.

In India, the highest area under paddy is in Uttar Pradesh (5.95 million ha), followed by West Bengal (5.46 million ha), Andhra Pradesh (4.10 million ha), Odisha (4.02 million ha), and Karnataka (1.39 million ha). Production-wise, West Bengal stands first (14.80 million tonnes), followed by Uttar Pradesh (14.03 million tonnes), Andhra Pradesh (12.89 million tonnes), and Karnataka (4.04 million tonnes). The highest yield is observed in the state of Punjab (3741 $\mathrm{kg} / \mathrm{ha}$ ) followed by Tamil Nadu (3423 kg/ha), Andhra Pradesh (3146 kg/ha) and Karnataka (2897 kg/ha) (Anonymous, 2012).

The area under rice in Jammu and Kashmir is 0.3 million hectares with a productivity of $2123.4 \mathrm{~kg} / \mathrm{ha}$ and in Kashmir valley rice is grown over an area of 1.44 lakh hectares with a production of 3.8 lakh tons and a productivity of $2688.3 \mathrm{~kg} / \mathrm{ha}$ (Anonymous, 2016a).

In Bandipora District of J\&K, the area under rice during 2016-17 was11746 hectares (Anonymous, 2016b).

\section{Materials and Methods}

In this study, an ex-post-facto research design was used in the investigation because it is a sort of fact finding operation with adequate interpretation. Kashmir valley consists of 12 districts and the present study was conducted in District Bandipora of Jammu and Kashmir. In District Bandipora, Agricultural Sub Division Bandipora was selected purposively on the basis of area under Rice crop. As Agricultural Sub Division Bandipora consists of seven Agricultural Zones and among these Agricultural Zones, Zone Bandipora was selected for the present study. Agricultural Zone Bandipora consists of forty-two villages, out of which only four villages were selected purposively. From each selected village 25 respondents were selected and a total sample of 100 rice growers were selected for the present study by random sampling method.

\section{Results and Discussion}

\section{Extent of adoption of the recommended} package of practices

\section{Adoption of improved varieties}

From the data in the Table- 1 it is evident that, majority $(49.00 \%)$ of the respondents were cultivating china-1039 (non-recommended) variety of rice, followed by 22.00 per cent who cultivated K-39 (non-recommended), whereas 17.00 per cent and 12.00 per cent of the respondents were cultivating Jhelum (recommended) and SR-1 (recommended) varieties of rice respectively. 
From the data in Table- 2 it is clear that, majority $(84.00 \%)$ of the respondents had sown the seed at the recommended time (April 15-May 20) followed by 16.00 per cent of the respondents who had sown the seed before the recommended time.

From the data in Table-3 it is clear that, majority $(74.00 \%)$ of the respondents had adopted more than recommended seed rate, followed by 22.00 per cent of the respondents who had adopted the recommended seed rate $(2.5-3 \mathrm{~kg} / \mathrm{kanal})$ and only 4.00 per cent of the respondents had adopted less than recommended seed rate for raising rice nursery.

From the data in Table-4 it is evident that, majority $(96.00 \%)$ of the respondents had not adopted any seed treatment. While as, 4.00 per cent of the respondents had adopted recommended seed treatment for treating the seed before sowing.

The data given in Table-5 shows that, majority $(97.00 \%)$ of the respondents had adopted less than recommended spacing while transplanting the seedlings. Only 03.00 per cent of the respondents had adopted recommended spacing for transplanting the seedlings of rice.

From the data in Table-6 it is clear that, majority $(42.00 \%)$ per cent of the respondents had adopted the recommended number of ploughings for puddling. Whereas, 37.00 per cent and 21.00 per cent of the respondents had adopted less than recommended and more than recommended number of ploughings for puddling respectively.

The data in the Table-7 revealed that, majority $(81.00 \%)$ of the respondents had transplanted seedlings after 10 days more than recommended age, followed by 14.00 per cent of the respondents had transplanted seedlings of recommended age (25-30 days old seedlings), whereas only 5.00 per cent of the respondents had transplanted seedlings after 5 days more than recommended age.

From the data in Table- 8 it is evident that, cent per cent of the respondents had adopted more than recommended number of seedlings per hill.

From the data in Table-9 it is clear that, majority $(54.00 \%)$ of the respondents had applied more than recommended quantity of FYM, whereas 33.00 percent of the respondents had applied the recommended quantity of FYM and only 13.00 per cent of the respondents had applied less than recommended quantity of FYM to rice crop.

The data in the Table-10 revealed that, majority $(63.00 \%)$ of the respondents had applied more than recommended quantity of urea. Whereas, 37.00 per cent of the respondents had applied recommended (12 $\mathrm{kg} / \mathrm{kanal}$ ) quantity of urea to their rice crop.

The data in the Table-11 revealed that, majority $(73.00 \%)$ of the respondents had done less than recommended number of urea applications, followed by 27.00 per cent of the respondents who had done recommended number of urea applications.

The data in the Table-12 revealed that, majority $(48.00 \%)$ of the respondents had applied less than recommended quantity of DAP, followed by 37.00 per cent of the respondents who applied the recommended $(6.5 \mathrm{kgs} / \mathrm{kanal})$ quantity of DAP. Whereas, 15.00 per cent of the respondents had applied more than recommended quantity of DAP to the rice crop.

The data in Table-13 revealed that, majority (73.00\%) of the respondents had applied less than recommended quantity of MOP, 
followed by 21.00 per cent of respondents who applied more than recommended quantity of MOP. Whereas, 6.00 of the respondents had applied the recommended quantity of MOP to the rice crop.

The data in the Table-14 indicated that, majority $(42.00 \%)$ of the respondents had applied more than recommended number of irrigations, followed by 31.00 per cent of the respondents who applied less than recommended number of irrigations and only 27.00 per cent of the respondents had applied recommended (once in 6 days) no. of irrigation to their rice crop.
From the data in Table-15 it is evident that, majority $(61.00 \%)$ of the respondents had applied recommended weedicide (Butachlor) for control of weeds. Whereas, 39.00 per cent of the respondents had not used any chemical weedicide for control of weeds.

The data in the same table also revealed that out of 61 respondents, 86.88 per cent of respondents had applied more than recommended doses of weedicide, while 8.19 per cent of respondents had applied recommended doses of weedicide and 4.91 per cent of respondents had applied less than recommended doses of weedicide to their rice crop.

Table.1 Distribution of growers on the basis of adoption of different varieties by Rice Growers $(\mathrm{N}=100)$

\begin{tabular}{|c|c|c|c|}
\hline \multirow{2}{*}{ S. No. } & \multirow{2}{*}{ Varieties Adopted } & \multicolumn{2}{|c|}{ Growers } \\
\hline & & Frequency & Percentage \\
\hline A. & Recommended & & \\
\hline 1. & Jhelum (Recommended) & 17 & 7.00 \\
\hline 2. & SR-1 & 12 & 12.00 \\
\hline B & Non recommended & & \\
\hline 1. & China-1039 & 49 & 49.00 \\
\hline 2. & K-39 & 22 & 22.00 \\
\hline
\end{tabular}

Table.2 Distribution of growers on the basis of time of seed sowing for nursery raising ( $\mathrm{N}=100)$

\begin{tabular}{|l|l|c|c|}
\hline & \multicolumn{2}{|c|}{ Growers } \\
\hline S. No. & \multicolumn{1}{|c|}{ Time of seed sowing } & Frequency & Percentage \\
\hline 1. & Recommended (April 15-May 20) & 84 & 84.00 \\
\hline 2. & Before recommended time (April 1-april 14) & 16 & 16.00 \\
\hline
\end{tabular}

Table.3 Distribution of respondents on the basis of seed rate for raisingRice nursery ( $\mathrm{N}=100)$

\begin{tabular}{|l|l|c|c|}
\hline & \multicolumn{1}{|c|}{ Seed rate } & \multicolumn{2}{c|}{ Growers } \\
\cline { 2 - 4 } S. No. & \multicolumn{1}{|c|}{ Frequency } & Percentage \\
\hline 1. & Recommended $(2.5-3 \mathrm{~kg} / \mathrm{kanal})$ & 22 & 22.00 \\
\hline 2. & $\begin{array}{l}\text { Less than recommended seed rate }(1.5-2 \\
\mathrm{kg} / \mathrm{kanal})\end{array}$ & 04 & 4.00 \\
\hline 3. & $\begin{array}{l}\text { More than recommended seed rate }(3-5 \\
\mathrm{kg} / \text { kanal })\end{array}$ & 74 & 74.00 \\
\hline
\end{tabular}


Table.4 Distribution of respondents on the basis of seed treatment $(\mathrm{N}=100)$

\begin{tabular}{|l|l|c|c|}
\hline & \multicolumn{2}{|c|}{ Seed Treatment } & \multicolumn{2}{c|}{ Growers } \\
\cline { 3 - 4 } S. No. & & Frequency & Percentage \\
\hline 1. & Recommended & 04 & 4.00 \\
\hline 3. & No adoption & 96 & 96.00 \\
\hline
\end{tabular}

*Mancozeb 75 WP + Carbendazium 50WP (3g/Kg seed)

Table.5 Distribution of respondents on the basis of adoption of spacing in Rice $(\mathrm{N}=100)$

\begin{tabular}{|l|l|c|c|}
\hline & \multicolumn{2}{|c|}{ Spacing adopted } & \multicolumn{2}{c|}{ Growers } \\
\cline { 3 - 4 } S. No. & & Frequency & Percentage \\
\hline 1. & Recommended $(15 \times 15 \mathrm{~cm})$ & 03 & 3.00 \\
\hline 2. & Less than recommended & 97 & 97.00 \\
\hline
\end{tabular}

Table.6 Distribution of respondents on the basis of No. of ploughings followed for puddling by Rice growers $(\mathrm{N}=100)$

\begin{tabular}{|l|l|c|c|}
\hline & \multicolumn{2}{|c|}{ No. of ploughings } & \multicolumn{2}{|c|}{ Growers } \\
\cline { 3 - 4 } S. No. & & Frequency & Percentage \\
\hline 1. & Recommended (2-3) & 42 & 42.00 \\
\hline 2. & Less than recommended & 37 & 37.00 \\
\hline 3. & More than recommended & 21 & 21.00 \\
\hline
\end{tabular}

Table.7 Distribution of respondents on the basis of age of seedlings used for transplanting by Rice growers $(\mathrm{N}=100)$

\begin{tabular}{|l|l|c|c|}
\hline & \multicolumn{2}{|c|}{ Age of seedling } & \multicolumn{2}{c|}{ Growers } \\
\cline { 3 - 4 } S. No. & & Frequency & Percentage \\
\hline 1. & Recommended (25-30 days old seedlings) & 14 & 14.00 \\
\hline 2. & 5 days more than recommended & 05 & 05.00 \\
\hline 3. & 10 days more than recommended & 81 & 81.00 \\
\hline
\end{tabular}

Table.8 Distribution of respondents on the basis of No. of seedlings/hill used for transplanting by Rice growers $(\mathrm{N}=100)$

\begin{tabular}{|l|l|c|c|}
\hline \multirow{2}{*}{ S. No. } & \multicolumn{2}{|c|}{ No. of seedlings/hill } & \multicolumn{2}{c|}{ Growers } \\
\cline { 3 - 4 } & & Frequency & Percentage \\
\hline 1. & Recommended (2-3) & 00 & 00.00 \\
\hline 2. & Less than recommended & 00 & 00.00 \\
\hline 3. & More than recommended & 100 & 100.00 \\
\hline
\end{tabular}


Table.9 Distribution of respondents on the basis of quantity of FYM applied to rice crop by Rice growers $(\mathrm{N}=100)$

\begin{tabular}{|c|c|c|c|}
\hline \multirow[b]{2}{*}{ S. No. } & \multirow[t]{2}{*}{ Quantity of FYM } & \multicolumn{2}{|c|}{ Growers } \\
\hline & & Frequency & Percentage \\
\hline 1. & Recommended (500kgs/kanal) & 33 & 33.00 \\
\hline 2. & Less than recommended & 13 & 13.00 \\
\hline 3. & More than recommended & 54 & 54.00 \\
\hline
\end{tabular}

Table.10 Distribution of respondents on the basis of quantity of Urea to Rice crop $(\mathrm{N}=100)$

\begin{tabular}{|l|l|c|c|}
\hline & \multicolumn{2}{|c|}{ Quantity of Urea } & \multicolumn{2}{c|}{ Growers } \\
\cline { 3 - 4 } S. No. & & Frequency & Percentage \\
\hline 1. & Recommended (12 kg/kanal) & 37 & 37.00 \\
\hline 3. & More than recommended & 63 & 63.00 \\
\hline
\end{tabular}

Table.11 Distribution of respondents on the basis no. of applications of Urea to Rice crop $(\mathrm{N}=100)$

\begin{tabular}{|l|l|c|c|}
\hline & \multicolumn{2}{|c|}{ No. of applications of urea } & \multicolumn{2}{c|}{ Growers } \\
\cline { 3 - 4 } S. No. & & Frequency & Percentage \\
\hline 1. & Recommended (3) & 27 & 27.00 \\
\hline 2. & Less than recommended & 73 & 73.00 \\
\hline
\end{tabular}

Table.12 Distribution of respondents on the basis of quantity DAP to Rice crop $(\mathrm{N}=100)$

\begin{tabular}{|l|l|c|c|}
\hline \multirow{2}{*}{ S. No. } & \multicolumn{2}{|c|}{ Quantity of DAP } & \multicolumn{2}{c|}{ Growers } \\
\cline { 3 - 4 } & & Frequency & Percentage \\
\hline 1. & Recommended (6.5kgs/kanal) & 37 & 37.00 \\
\hline 2. & Less than recommended & 48 & 48.00 \\
\hline 3. & More than recommended & 15 & 15.00 \\
\hline
\end{tabular}

Table.13 Distribution of respondents on the basis of quantity MOP to Rice crop (N=100)

\begin{tabular}{|l|l|c|c|}
\hline & \multicolumn{2}{|c|}{ Quantity of MOP } & \multicolumn{2}{c|}{ Growers } \\
\cline { 3 - 4 } S. No. & & Frequency & Percentage \\
\hline 1. & Recommended $(2.5 \mathrm{kgs} / \mathrm{kanal})$ & 06 & 6.00 \\
\hline 2. & Less than recommended & 73 & 73.00 \\
\hline 3. & More than recommended & 21 & 21.00 \\
\hline
\end{tabular}


Table.14 Distribution of respondents on the basis of no. of irrigations in Rice $(\mathrm{N}=100)$

\begin{tabular}{|l|l|c|c|}
\hline & \multicolumn{2}{|c|}{ No. of irrigations } & \multicolumn{2}{c|}{ Growers } \\
\cline { 3 - 4 } S. No. & & Frequency & Percentage \\
\hline 1. & Recommended (once in 6 days) & 27 & 27.00 \\
\hline 2. & Less than recommended & 31 & 31.00 \\
\hline 3. & More than recommended & 42 & 42.00 \\
\hline
\end{tabular}

Table.15 Distribution of respondents on the basis of weed management practices followed in Rice crop $(\mathrm{N}=100)$

\begin{tabular}{|l|l|c|c|}
\hline \multicolumn{1}{|r|}{ S. No. } & \multicolumn{1}{c|}{ Weed management } & \multicolumn{2}{c|}{ Growers } \\
\cline { 3 - 4 } & & Frequency & Percentage \\
\hline 1. & Recommended (Butachlor) & 61 & 1.00 \\
\hline 2. & No chemical control was adopted & 39 & 39.00 \\
\hline & Dose & & $\mathbf{N}=\mathbf{6 1}$ \\
\hline $\mathbf{1 .}$ & Recommended (75gm/kanal) & 05 & 8.19 \\
\hline 2. & Less than recommended & 03 & 4.91 \\
\hline $\mathbf{3 .}$ & More than recommended & 53 & 86.88 \\
\hline
\end{tabular}

Table.16 Distribution of respondents on the basis of diseases management followed by the rice growers

\begin{tabular}{|l|l|c|c|}
\hline \multicolumn{1}{|c|}{ S. No. } & \multicolumn{1}{c|}{ Disease and pest incidence } & \multicolumn{2}{c|}{ Growers } \\
\cline { 3 - 4 } & & Frequency & Percentage \\
\hline 1. & Rice Blast & 67 & 7.00 \\
\hline 2. & Brown Spot & 11 & 11.00 \\
\hline 3. & No disease & 22 & 22.00 \\
\hline ntrol measures recommended & Mancozeb 75 WP + Carbendazim 50 & 00 & 00 \\
\hline 1. & WP $(50 \mathrm{~g} / 100$ litre water $)$ & & \\
\hline
\end{tabular}

Table.17 Distribution of respondents on the basis of pest management followed by the rice growers

\begin{tabular}{|l|l|c|c|}
\hline \multirow{2}{*}{$\begin{array}{c}\text { S. } \\
\text { No. }\end{array}$} & Disease and pest incidence & \multicolumn{2}{c|}{ Growers } \\
\cline { 1 - 4 } & & Frequency & Percentage \\
\hline 1. & Paddy Grass Hopper & 82 & 2.00 \\
\hline 2. & No Pest incidence & 18 & 18.00 \\
\hline ontrol measures recommended & \multicolumn{2}{c}{} \\
\hline 1. & $\begin{array}{l}\text { Chlorpyriphos } \\
\text { EC@ 100ml/100Litre water }\end{array}$ & 20 & 00 \\
\hline
\end{tabular}


Table.18 Distribution of respondents on the basis of harvesting time ( $\mathrm{N}=100)$

\begin{tabular}{|l|l|c|c|}
\hline \multicolumn{2}{|c|}{ S. No. } & \multicolumn{1}{c|}{ Time of harvesting } & \multicolumn{2}{c|}{ Growers } \\
\cline { 3 - 4 } & & Frequency & Percentage \\
\hline 1. & Recommended (150-165 days) & 28 & 3.00 \\
\hline 2. & 3-5 days less than recommended & 16 & 16.00 \\
\hline 3. & 5-10 days more than recommended & 56 & 56.00 \\
\hline
\end{tabular}

Table.19 Overall adoption level of respondents $(\mathrm{N}=100)$

\begin{tabular}{|l|l|c|c|}
\hline \multirow{2}{*}{ S. No. } & \multicolumn{1}{|c|}{ Adoption } & \multicolumn{2}{|c|}{ Growers } \\
\cline { 3 - 4 } & & Frequency & Percentage \\
\hline 1. & Low (18-21) & 26 & 26.00 \\
\hline 2. & Medium (22-24) & 67 & 67.00 \\
\hline 3. & High (24-28) & 07 & 07.00 \\
\hline
\end{tabular}

The data given in Table-16 shows that, majority $(67.00 \%)$ of the respondents faced the problem of Blast in rice, followed by 22.00 per cent of the respondents who does not face any disease problem in their rice field and 11.00 per cent of the respondents faced the problem of Brown spot in rice. None of the grower who faced the disease problem in rice field had followed any chemical measures to manage the disease.

The data given in Table-17 shows that, majority $(82.00 \%)$ of the respondents faced the problem of grass hopper in their rice field followed by 18.00 per cent of the respondents who does not face any pest problem in their rice field. None of the grower who faced the problem of pests in rice field had followed any chemical measures to manage the pests.

The data given in Table-18 shows that, majority $(56.00 \%)$ of the respondents had harvested rice crop in more than recommended time. Whereas, 28.00 per cent of the respondents had harvested rice crop on recommended (150-165 days) time and only 16.00 per cent of the respondents harvested their rice crop in less than recommended time.
The data in the Table-19 revealed that, majority $(67.00 \%)$ of the respondents were having medium level of adoption, whereas 26.00 per cent and 7.00 per cent of the respondents were having low and high level of adoption respectively. The findings are in line with the findings of Solanki, (2009) and Singh et al., (2014).

In conclusion the majority $(49.00 \%)$ of the growers are cultivating non-recommended rice variety, $(84.00 \%)$ are sowing rice for raising nursery at recommended time, $(74.00 \%)$ growers used more than recommended seed rate, $(96.00 \%)$ growers had not adopted any seed treatment, $(97.00 \%)$ growers adopted less than recommended spacing for transplanting the seedlings, $(42.00 \%)$ growers had done recommended no. of ploughings, $(81.00 \%)$ growers transplanted seedlings after 10 days more than recommended time, (100.00\%) growers used more than recommended no. of seedlings per hill, $(54.00 \%)$ had applied more than recommended quantity of FYM, (63.00\%) had applied more than recommended quantity of urea, (48.00\%) had applied less than the recommended quantity of DAP, $(73.00 \%)$ had applied less than recommended quantity of 
MOP, (42.00\%) had applied more than recommended no. of irrigation, $(61.00 \%)$ had applied recommended weedicide. Growers who faced the problems of diseases and pests in their fields have not adopted any chemical control measures for disease management.

Majority $(67.00 \%)$ of growers had medium level of adoption followed 26.00 per cent and 7.00 per cent of the growers had low and high level of adoption respectively.

\section{References}

Anonymous (2004). Agricultural production report 2004-05, 4 pp.

Anonymous (2012). Agricultural Statistics at a Glance, Directorate of Economics and Statistics, Department of Agriculture and Co-operation, Ministry of Agriculture, Academic foundation, pp. 64-66

Anonymous, (2012-13). Annual report, 2012-
13, Department of Agriculture and Cooperation.

Anonymous, (2016 a). Digest of Statistics, Directorate of Economics and Statistics, Jammu and Kashmir, pp: 149.

Anonymous, (2016b). Directorate of Economics and Statistics, Department of Agricultural and Cooperation, Jammu and Kashmir.

Singh, D. P and Yadav, S. K. 2014. Knowledge and Adoption gap of Tribal farmers of Bastar towards Rice Production Technology. American International Journal of Research in Humanities, Arts and Social Sciences 5(1): 54-56.

Solanki,D.L. 2009. A study on adoption behaviour of vegetable growers in relation to their socio-economic and psycho characteristics in Khandwa district of Madhya Pradesh. M.Sc.(Ag.) Thesis, submitted to R.A.K. College of Agriculture, Sehore (M.P.).

\section{How to cite this article:}

Shijaatt Hussain Bhat, Farhana, Anjali Tomar and S. S. Kubrevi. 2020. A Study on Adoption of Recommended Package of Practices by Rice Growers in Bandipora District of Jammu and Kashmir. Int.J.Curr.Microbiol.App.Sci. 9(08): 969-977. doi: https://doi.org/10.20546/ijcmas.2020.908.105 